\title{
Ecotoxicological Assessment of Sediment Leachates of Small Watercourses in the Brno City Suburban Area (South Moravia, Czech Republic)
}

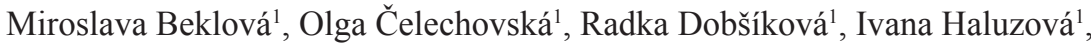 \\ Helena Králová 2 , Jitka Malá2, Helena Modrá1, Magdalena Ostrá1, Zdeňka Svobodová1 \\ ${ }^{1}$ University of Veterinary and Pharmaceutical Sciences Brno, Faculty of Veterinary Hygiene and Ecology, \\ Brno, Czech Republic \\ ${ }^{2}$ University of Technology Brno, Faculty of Civil Engineering, Brno, Czech Republic
}

Received December 3, 2008

Accepted September 8, 2009

\begin{abstract}
Sediments of two small watercourses Leskava and Troubsky Brook in the Brno city suburban area were examined for their ecotoxicity. Using a standard procedure, extracts of the sediments were prepared for diagnostic tests. These extracts were tested for acute toxicity to fresh-water organisms. The ecotoxicological tests were performed on the fresh-water alga Pseudokirchneriella subcapitata, the vascular water plant Lemna minor, on a representative of invertebrates - the water flea Daphnia magna and on the Xenopus laevis frog embryo and luminiscent Vibrio fischeri bacteria. Possible toxic effects were evaluated using the test determining the inhibition of the growth of white mustard root Sinapis alba. Results of ecotoxicological assessment of sediment leachates showed that their quality varied significantly during the year. Differences were found between results of sediment evaluations from different collection profiles, which may indicate effects of point source pollution. Of the ecotoxicological tests used, the most sensitive organisms included the green algae Pseudokirchneriella subcapitata, bioluminiscent bacteria Vibrio fischeri and the African clawed frog Xenopus laevis. The highest concentrations of arsenic were found by chemical analysis in both spring and autumn sediment leachate samples collected at Site L1 (Leskava). The highest organic pollutant concentrations were found in autumn sediment leachate samples from Site L1. In total PAH sums, phenanthrene was the dominant pollutant at all the sites investigated.
\end{abstract}

Ecotoxicity, Pseudokyrchneriella subcapitata, Daphnia magna, Lemna minor, Sinapis alba, Vibrio fischeri, Xenopus laevis

Small water courses represent about $80 \%$ of the total length of rivers in the Czech Republic. The streams in the agricultural landscape lost their natural characteristics and their conditions are strongly affected. Two small water courses Leskava and Troubsky Brook (with catchment areas of 20.6 and $29.8 \mathrm{~km}^{2}$ ) affected by diffuse (farming) and point (sewage) pollution sources were studied in the Brno city suburban area (South Moravia, Czech Republic). Surface waters receive a considerable load of nutrients as well as anthropogenic chemicals and their metabolites from atmospheric deposition (Mast et al. 2007; Sun et al. 2007; Perceval et al. 2006), runoff from agricultural areas (Burkholder et al. 2007; Konstantinou et al. 2006) and urban surfaces (Comoutto and Chiron 2005; Billen et al. 2001). Sediments have been recognized as both a major sink and a potential source of persistent toxic chemicals in aquatic ecosystems (Hollert et al. 2002). Recent study assessed the ecotoxicological risk of river sediments by means of monitoring biological effects in toxicity tests as a single line of evidence, since chemical analyses of water quality and monitoring of different hydrological and biological indicators failed to determine a limiting factor for aquatic organisms. Results of the applied bioassays clearly show that cytotoxic, genotoxic, estrogenic, embryotoxic, teratogenic and mutagenic potentials are associated with local sediments (Kammann et al. 2005; Keiter et al. 2006). Increasing demands for routine toxicity screening for ecological risk assessment necessitate the use of battery of validated bioassays. In an effort to assess the potential toxicological risk to the

Address for correspondence:

Prof. RNDr. Miroslava Beklová, CSc.

Department of Veterinary Ecology and Environmental Protection

University of Veterinary and Pharmaceutical Sciences Brno

Phone: +420541562652

Fax: +420541562657

E-mail: beklovam@vfu.cz

Palackeho 1-3, 61242 Brno, Czech Republic

http://www.vfu.cz/acta-vet/actavet.htm 
aquatic environment in the selected suburban region near Brno five tests were conducted with six samples of aqueous sediment extracts from two small watercourses. The primary objectives of the study were to determine specific sensitivity of each test and to compare differences between sites and between spring and autumn samples.

\section{Materials and Methods}

Sediments of two small watercourses Leskava and Troubsky Brook in the Brno city suburban area were examined for their ecotoxicity. In May and September 2007, sediment samples were collected at three sites along two streams, i.e. the Troubsky Brook (Sites T1, T2 and T3) and the Leskava (Sites L1, L2 and L3) - see Fig. 1. At each site, composite bottom sediments were collected into $950 \mathrm{ml} \mathrm{PE}$ sample containers and stored at $-15^{\circ} \mathrm{C}$. The collection of sediment samples was performed from an area of about $5 \mathrm{~m}^{2}$ as a surface sampling in the depth of about $5-15 \mathrm{~cm}$. The pooled sample was obtained from five collections in each locality. The method used for the sample collection complies with ISO 5667-12 (1998). A total of 12 sediment samples were collected (6 during spring thaw and 6 in autumn). Methods for analysing the ecotoxicity of wastes (CSN EN 14735, 2007) were employed to determine the ecotoxicity of sediments in the present study. Using a standard procedure (Machova et al. 1994) and the Method for determination of ecotoxicity in wastes (2007), extracts of the sediments were prepared for diagnostic tests. Sediments were shaken together with deionized water at the ratio of $100 \mathrm{~g}$ of dry matter and $900 \mathrm{ml}$ of water for $24 \mathrm{~h}$. After separation of the solid phase, aqueous sediment leachates were obtained. These leachates were then enriched by salts similarly to dilution water (aqueous solution is enriched with nutrients in the same way as the standard nutritious solution for the purpose of tests on the fresh-water alga Pseudokirchneriella subcapitata and the vascular water plant Lemna minor). These extracts were tested for acute toxicity to fresh-water organisms. First, an estimate of toxicity was made using the non-diluted leachate and individual testing organisms. When it was positive, further tests to determine values such as $\mathrm{EC}_{50}$ and $\mathrm{IC}_{50}$ were performed. Tests of ecotoxicity of aqueous leachates were performed using water fleas Daphnia magna, freshwater algae Pseudokirchneriella subcapitata, vascular water plants Lemna minor, seeds of higher plant Sinapis alba, bacteria Vibrio fischeri and amphibians Xenopus laevis.

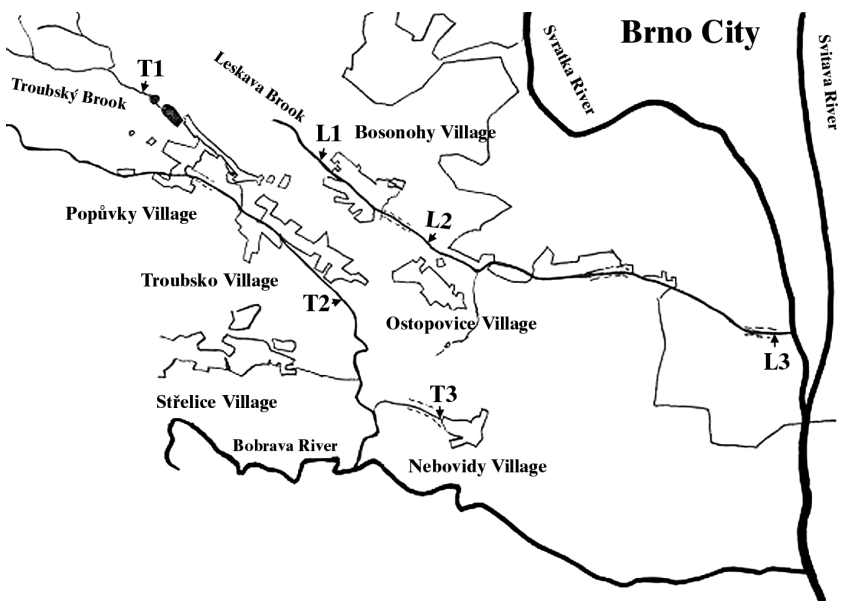

Fig. 1. Map of studied catchments with sampling sites

The following ecotoxicological indicators were analyzed in the leachates:

Growth inhibition of the freshwater alga Pseudokirchneriella subcapitata

Pre-cultures as well as tests were performed in the nutrient medium as described in the norm CSN EN ISO 8692 (2005), in Erlenmayer flasks of $250 \mathrm{ml}$ volume. Incubation was performed in the growth incubator at 25 $\pm 2{ }^{\circ} \mathrm{C}$ and using continual light regime of $6000 \mathrm{~lx}$ and manual stirring once a day. The density of algal cells in the suspension was evaluated every $24 \mathrm{~h}$ using the Bürker's counting cell and light microscopy. The test was conducted for $72 \mathrm{~h}$. Then the inhibition/stimulation of growth of the algal biomass was calculated using comparisons of areas under the growth curves of the algal cultures in the control and tested samples $\left(\mathrm{I}_{\AA}\right)$ and using comparisons of growth rates of the algal cultures in tested solutions and the control $\left(\mathrm{I}_{\mu}\right)$.

Mobility inhibition of the crustacean - water flea Daphnia magna

Juvenile water fleas aged less than $24 \mathrm{~h}$ were exposed to different concentrations of the tested leachate under 
precisely defined conditions of temperature $\left(20 \pm 2{ }^{\circ} \mathrm{C}\right)$ and light regime (photoperiod of $16 \mathrm{~h}$ of light and $8 \mathrm{~h}$ of dark) for $48 \mathrm{~h}$ (CSN EN ISO 6341, 1997). At the end of the test, numbers of immobilized specimens were counted and using the probit analysis we calculated the value of $48 \mathrm{hEC}_{50}$ (effect concentration).

Growth inhibition of the vascular water plant - Lemna minor

A stock culture of vascular water plant duckweed Lemna minor originated in the laboratory cultivation. SIS (Swedish Standard) was used as a solution for the growth of duckweed. The plants were grown in glass beakers in SIS medium ( $\mathrm{pH} 6.5 \pm 0.2)$ in a temperature-controlled chamber $\left(24 \pm 2{ }^{\circ} \mathrm{C}\right)$. Controls and the tested sample were started with $150 \mathrm{ml}$ of wastewater and 10 fronds per treatment. They were counted every $24 \mathrm{~h}$. After 7 days, the inhibitory/stimulatory effects on the growth $\left(\mathrm{I}_{\mathrm{r}} \%\right.$ ) were examined and the value $\mathrm{IC}_{50}$ was determined according to the valid standard (CSN EN ISO 20079, 2007).

\section{Luminescence inhibition of the Vibrio fischeri}

Liquid-dried luminescent bacteria Vibrio fischeri of the strain NRRL-B-11177, Reactivation solution and Standard solution $\left(7.5 \% \mathrm{NaCl}\right.$ ) were obtained from Dr. Lange $\mathrm{GmbH}$ (Düsseldorf, Germany), and stored at $-18^{\circ} \mathrm{C}$ until use. LUMIStox 300 (Dr. Lange) with the thermostat unit was used for measuring. This bioassay measures the emitted light from bioluminescent marine bacteria. Inhibition of cellular activity causes a decrease of respiration resulting in a decrease of luminescence. We used glass cuvettes with reactivated bacteria and the prepared dilution series. The measuring time was 15 and $30 \mathrm{~min}$. Values of $20 \%$ effective concentration $\left(\mathrm{EC}_{20}\right)$ and $50 \%$ effective concentration $\left(\mathrm{EC}_{50}\right)$ were determined according to the valid standard (CSN EN ISO11348-2, 2000).

Embryotoxicity and teratogenity of the Xenopus laevis frog embryo

FETAX test was conducted as described in ASTM E1439-98. Groups of 20 normally developing blastula-stage embryos were placed in $60 \mathrm{~mm}$ covered plastic Petri dishes containing control or treatment solutions. For each test, selected concentrations of each sample were tested in duplicate. Negative control group was designated four separate dishes, each with 20 embryos exposed to FETAX solution alone. The FETAX solution consisted of $625 \mathrm{mg}$ of $\mathrm{NaCl}, 96 \mathrm{mg}$ of $\mathrm{NaHCO}_{3}, 75 \mathrm{mg} \mathrm{MgSO}, 60 \mathrm{mg}$ of $\mathrm{CaSO}_{4} \cdot \mathrm{H}_{2} \mathrm{O}, 30 \mathrm{mg}$ of $\mathrm{KCl}$ and $15 \mathrm{mg}$ of $\mathrm{CaCl}_{2}$ per litre of solution. Each treatment and control contained $10 \mathrm{ml}$ of solution. Embryos were cultured at $23.0 \pm 1.0^{\circ} \mathrm{C}$. All solutions were changed every $24 \mathrm{~h}$ during the 4 day test and dead embryos were removed every 12 h. Following a 96-h exposure (stage 46 of embryos), the embryos were euthanized using water solution with $\mathrm{CO}_{2}$ and fixed in $3 \%$ formalin ( $\mathrm{pH} 7.0$ ). The number of malformed embryos, determination of malformation and head-tail length of embryos was determined using a dissecting microscope. The results are presented as \% of length of the control group (control $=100 \%$ ).

Growth inhibition of the white mustard root - Sinapis alba

Mustard (Sinapis alba) seeds were guaranteed seed corn, healthy looking and similar sized with $90 \%$ germinating capacity. The seeds were germinated for 3 days in the thermostat in the dark in Petri dishes with a filter paper on the bottom. The temperature in the thermostat was kept at $20 \pm 2{ }^{\circ} \mathrm{C}$. The dishes were covered by a glass cap in order to prevent loss due to evaporation. A total of $10 \mathrm{ml}$ of wastewater were added into each dish. In all, 30 seeds were spread onto the surface of the filter paper. After 3 days of exposure to solutions with wastewater, the length of roots (in $\mathrm{cm}$ ) was measured. The percentage of root inhibition/stimulation (I \%) in comparison to the control and the value $\mathrm{IC}_{50}$ were determined according to the valid standard (Machova et al. 1994).

\section{Heavy metals}

Heavy metals $(\mathrm{Cd}, \mathrm{Pb}, \mathrm{As})$ in leachates were determined by electrothermic atomization - atomic absorption spectrometry (AAS) using the apparatus ContrAA 700 (Analytik Jena, Germany). Prior to analysis of Cd and $\mathrm{Pb}$, leachates were acidified by nitric acid to the overall concentration of $0.075 \mathrm{~mol} \cdot \mathrm{l}^{-1}$. Limits of detection

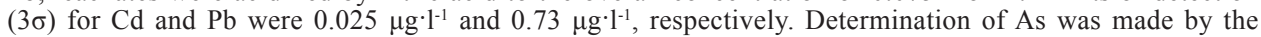
hydride technique AAS after acidification by hydrochloric acid to $4.7 \mathrm{~mol}^{\cdot-1}$ and $\mathrm{As}^{\mathrm{V}}$ was reduced to $\mathrm{As}^{\mathrm{III}}$. The limit of detection was $0.15 \mu \mathrm{g} \cdot \mathrm{l}^{-1}$. Mercury concentrations were determined using a single-purpose coldvapour AMA 254 mercury analyzer (Altec s.r.o., CZ) with the $0.01 \mathrm{ng} \mathrm{Hg}$ detection limit. Certified reference materials, i.e., aqueous calibration solutions ASTASOL ${ }^{\circledR}$ (Analytika s.r.o. CZ) of Cd, $\mathrm{Pb}, \mathrm{As}$ and $\mathrm{Hg}$, were used.

\section{Analyses of PAHs}

The analyses of PAHs (phenanthrene, anthracene, fluoranthene, pyrene, benzo[a]anthracene, chrysene, benzo $[b]$ fluoranthene, benzo $[k]$ fluoranthene, benzo $[a]$ pyrene, dibenzo $[a h]$ anthracene, benzo $[g h i]$ perylene and indeno[1,2,3-cd]pyrene) were performed by a combination of HPLC/FLD and GC/MS methods. Due to low selectivity of the fluorescence detector for two and three ring PAHs, the GC/MS method was used for the identification and quantification of low molecular weight $\mathrm{PAH}$.

The HPLC/FLD analysis was carried out by the HPLC system from Agilent (HP 1100 series) using a reversed phase column (Lichrospher PAH $250 \times 3 \mathrm{~mm}$ ) and water/methanol gradient for separation at $30{ }^{\circ} \mathrm{C}$. The ChemStatiton software was used for data processing. Gas chromatography mass spectrometric analysis was performed on the ThermoFinnigan TRACE DSQ ${ }^{\mathrm{TM}}$ Single Quadrupole GC/MS with a $30 \mathrm{~m}$ DB-5MS capillary column $(0.25 \mathrm{~mm}$ I.D. $\times 0.25 \mu \mathrm{m}$ film $)$ and operated in the electron ionization mode. The commercial GC/MS software Xcalibur 1.4 version was used for data processing. 
Table 1. The results of ecotoxicological tests

\begin{tabular}{|c|c|c|c|c|c|c|c|}
\hline \multicolumn{2}{|l|}{ Troubsky Brook } & \multicolumn{6}{|c|}{ Sampling site and season } \\
\hline \multirow[b]{2}{*}{ Test organism } & \multirow[b]{2}{*}{ Indicator } & \multicolumn{2}{|c|}{$\mathrm{T} 1$} & \multicolumn{2}{|c|}{$\mathrm{T} 2$} & \multicolumn{2}{|c|}{$\mathrm{T} 3$} \\
\hline & & $\stackrel{\infty}{\Xi}$ & $\begin{array}{l}\text { 声 } \\
\text { 导 } \\
\end{array}$ & $\stackrel{\infty}{\Xi}$ & 忐 & . & 志 \\
\hline \multirow{2}{*}{$\begin{array}{l}\text { Pseudokirchneriella } \\
\text { subcapitata }\end{array}$} & $\mathrm{I}_{\mu} \%$ & & 60.7 & 39.2 & 25.5 & 26.7 & \\
\hline & $\mathrm{I}_{\mathrm{A}} \%$ & & 79.4 & & 66.6 & 55.6 & 16.8 \\
\hline Daphnia magna & Immobility $\%$ & & & & & & \\
\hline \multirow{2}{*}{ Vibrio fischeri } & EC20 $(15,15) \%$ & 24.2 & 7.3 & 37.3 & 5.4 & 11.6 & 9.3 \\
\hline & EC50 $(15,15) \%$ & & & & 48.7 & & \\
\hline Lemna minor & $\mathrm{I}_{\mathrm{A}} \%$ & & 3.18 & 45.8 & 28.3 & & 10.7 \\
\hline Sinapis alba & $\mathrm{I} \%$ & 62.0 & 56.6 & 33.1 & & 1.5 & 20.5 \\
\hline \multirow{3}{*}{ Xenopus laevis } & Mortality \% & 6.7 & 11.7 & 6.7 & 21.7 & 6.7 & 25.0 \\
\hline & Malformed \% & 13.8 & 18.3 & 42.9 & 71.2 & 39.7 & 33.9 \\
\hline & Growth (\% of control) & $95.5^{\mathrm{a}}$ & $94.3^{\mathrm{a}, \mathrm{c}}$ & $82.2^{\mathrm{b}}$ & $87.3^{\mathrm{b}, \mathrm{c}}$ & $89.9^{\mathrm{c}}$ & $92.6^{\mathrm{a}, \mathrm{b}, \mathrm{c}}$ \\
\hline
\end{tabular}

\begin{tabular}{|c|c|c|c|c|c|c|c|}
\hline \multicolumn{2}{|l|}{ Leskava } & \multicolumn{6}{|c|}{ Sampling site and season } \\
\hline \multirow[b]{2}{*}{ Test organism } & \multirow[b]{2}{*}{ Indicator } & \multicolumn{2}{|c|}{$\mathrm{L} 1$} & \multicolumn{2}{|c|}{$\mathrm{L} 2$} & \multicolumn{2}{|c|}{ L3 } \\
\hline & & 离 & 声 & 泀 & $\underset{\Xi}{\Xi}$ & 葛 & $\begin{array}{l}\text { 䒠 } \\
\text { 至 }\end{array}$ \\
\hline \multirow{2}{*}{$\begin{array}{l}\text { Pseudokirchneriella } \\
\text { subcapitata }\end{array}$} & $I_{\mu} \%$ & 17.7 & 93.9 & 14.5 & 60.2 & & 61.4 \\
\hline & $I_{A} \%$ & 70.7 & 104.0 & 56.6 & 72.3 & & 84.5 \\
\hline Daphnia magna & Immobility \% & & & 100.0 & & & \\
\hline \multirow{2}{*}{ Vibrio fischeri } & EC20 $(15,15) \%$ & 32.6 & & 17.8 & 22.2 & & \\
\hline & EC50 $(15,15) \%$ & & 3.2 & 38.5 & & & \\
\hline Lemna minor & $\mathrm{I} \%$ & 1.5 & 13.1 & 103.7 & 13.5 & & \\
\hline Sinapis alba & I \% & 49.4 & 22.5 & 15.9 & 17.3 & & 32.7 \\
\hline \multirow{3}{*}{ Xenopus laevis } & Mortality \% & 3.3 & 18.3 & 100.0 & 28.3 & 10.0 & 5.0 \\
\hline & Malformed \% & 34.8 & 75.0 & - & 16.8 & 22.5 & 11.8 \\
\hline & Growth (\% of control) & $92.3^{\mathrm{a}, \mathrm{c}}$ & $85.9^{\mathrm{b}}$ & - & $95.0^{\mathrm{a}, \mathrm{c}}$ & $94.7^{\mathrm{a}}$ & $96.6^{\mathrm{a}}$ \\
\hline
\end{tabular}

Xenopus laevis - control-mortality-spring-9,7\%; autumn-6,7\% Malformed-spring-7\%; autumn-7,9\%

Statistical differences of growth (X. laevis) are compared among each other groups in spring and autumn, respectively

Values with superscript ${ }^{\mathrm{a}, \mathrm{b}, \mathrm{c}, \mathrm{d}}$ express significant difference $(p<0.01)$ between groups

$\mathrm{I} \mu \%$ - algal culture growth rate inhibition over a $72 \pm 2$-hour period compared to control

$\mathrm{I}_{\mathrm{A}} \%$ - freshwater algae growth rate inhibition over a $72 \pm 2$-hour period compared to control, as determined by a comparison of areas under growth curves

Immobility \% - immobilization (mortality) macroscopically observable inability of independent movement or death of Daphnia magna over a $48 \pm 2$-hour period

EC20 $(15,15)$ - test substance concentration that causes a $20 \%$ reduction of bacterial luminescence compared to control after a 15 -min contact with the sample at $15^{\circ} \mathrm{C}$

EC20 $(15,15)$ - test substance concentration that causes a $50 \%$ reduction of bacterial luminescence compared to control after a 15 -min contact with the sample at $15^{\circ} \mathrm{C}$

$\mathrm{I}_{\mathrm{A}} \%$ - duckweed growth rate inhibition - reduction of growth rate of duckweed in the sample tested compared to control calculated from the number of leaves after a 168 -h cultivation

I\% - root growth inhibition - difference in average length of roots of white mustard Sinapis alba in the sample tested compared to control $(72 \pm 2 \mathrm{~h})$

Mortality \% - death rate of African clawed frog embryos over a 96-h period

Malformations \% - occurrence of malformations among African clawed frog embryos after 96 hours

Growth ( $\%$ of control), control $=100 \%$

Control - dilution water (Daphnia magna, Sinapis alba), standard nutrient solution (Lemna minor,

Pseudokirchneriella subcapitata), normal saline solution (Vibrio fischeri) or standard FETAX solution (Xenopus laevis) according to methods of individual tests. 
Statistical analyses

Relationship between ecotoxicological tests and contaminants was computed by means of the Spearman correlation. Differences in the total length of frog tadpoles were evaluated by ANOVA and Tuckey test.

\section{Results and Discussion}

Results of the present ecotoxicological assessment of sediment leachates showed that their quality varied significantly during the year, which may be associated with the precipitation deficit in summer being more toxic in autumn. Significant differences were found between results of sediment evaluations from different collection profiles, which may indicate effects of point source pollution (sewage). Of the ecotoxicological tests used, the most sensitive organisms included the green algae Pseudokirchneriella subcapitata, bioluminiscent bacteria Vibrio fischeri and the African clawed frog Xenopus laevis. Characteristic malformation of Xenopus laevis embryos in the affected sites included gut deformities, axial flexure and multiple oedemas. In spring, significant inhibition of growth $(p<0.01)$ compared to other sediment leaches was detected in the sample collected at site T2. The lengths of embryos at the end of FETAX test from each site were found to be $\mathrm{T} 2<\mathrm{T} 3<\mathrm{L} 1<\mathrm{L} 3<\mathrm{T} 1$. Sediment leachates from sites T2, T3, L1 induced elevated rates of abnormal development. Sediment leaches from site L2 caused 100\% mortality of test embryos. In autumn, significant inhibition of growth was detected in sample L1 with comparison to samples T1, L2 and L3. The lengths of embryos from each site were found to be $\mathrm{L} 1<\mathrm{T} 2<\mathrm{T} 3<\mathrm{T} 1<\mathrm{L} 2<\mathrm{L} 3$. Results of ecotoxicological tests are summarized in Table 1. Results of heavy metal analyses showed that arsenic and lead are the most frequent metals. The highest concentrations of arsenic were found by chemical analysis in both spring and autumn sediment leachate samples collected at site L1 (Table 2). Arsenic is brought to the environment through natural and anthropogenic routes (emissions, use of certain insecticides, herbicides, etc.). Since arsenic accompanies phosphorus, it is found in the wash water. Arsenic has a considerable tendency to accumulate in bottom sediments (Pitter 1999). For that reason, issues relating to the arsenic content in aquatic organisms, and sea fish in particular, have attracted much attention (Lai et al. 2001).

Table 2. Chemical analyses of sediment leachates

\begin{tabular}{|c|c|c|c|c|c|c|c|}
\hline \multirow{3}{*}{\multicolumn{2}{|c|}{ Troubsky Brook }} & \multicolumn{6}{|c|}{ Sampling site profile } \\
\hline & & \multicolumn{2}{|c|}{ T1 } & \multicolumn{2}{|c|}{$\mathrm{T} 2$} & \multicolumn{2}{|c|}{ T3 } \\
\hline & & Spring & Autumn & Spring & Autumn & Spring & Autumn \\
\hline $\mathrm{Cd}$ & $\mu \mathrm{g} \cdot \cdot^{-1}$ & $<0.5$ & $<0.1$ & $<0.5$ & 0.65 & 2.04 & $<0.1$ \\
\hline $\mathrm{Pb}$ & $\mu \mathrm{g} \cdot \mathrm{l}^{-1}$ & 5.57 & $<2.0$ & $<2.0$ & 3.62 & 5.59 & $<2.0$ \\
\hline $\mathrm{Hg}$ & $\mu g \cdot \mathrm{l}^{-1}$ & 0.84 & 1.20 & 0.78 & 0.91 & 0.75 & 0.83 \\
\hline As & $\mu g \cdot \mathrm{l}^{-1}$ & $<0.5$ & 2.60 & 2.64 & 4.98 & 2.64 & 3.25 \\
\hline $\mathrm{pH}$ & - & 6.85 & 7.85 & 7.65 & 7.58 & 8.21 & 7.79 \\
\hline
\end{tabular}

\begin{tabular}{|c|c|c|c|c|c|c|c|}
\hline \multirow{3}{*}{ Leskava } & & \multicolumn{6}{|c|}{ Sampling site profile } \\
\hline & & \multicolumn{2}{|c|}{ L1 } & \multicolumn{2}{|c|}{ L2 } & \multicolumn{2}{|c|}{ L3 } \\
\hline & & Spring & Autumn & Spring & Autumn & Spring & Autumn \\
\hline $\mathrm{Cd}$ & $\mu \mathrm{g} \cdot \mathrm{l}^{-1}$ & $<0.5$ & $<0.1$ & $<0.5$ & $<0.1$ & 0.63 & 0.71 \\
\hline $\mathrm{Pb}$ & $\mu \mathrm{g} \cdot 1^{-1}$ & $<2.0$ & $<2.0$ & 3.79 & $<2.0$ & 7.63 & $<2.0$ \\
\hline $\mathrm{Hg}$ & $\mu \mathrm{g} \cdot 1^{-1}$ & 0.74 & 0.77 & 0.65 & 0.72 & 0.52 & 0.71 \\
\hline As & $\mu \mathrm{g} \cdot \mathrm{l}^{-1}$ & 8.77 & 11.35 & 1.03 & 1.83 & 2.39 & 9.88 \\
\hline $\mathrm{pH}$ & - & 7.63 & 7.65 & 7.84 & 7.80 & 7.21 & 7.53 \\
\hline
\end{tabular}

The highest organic pollutant concentrations were found in autumn sediment leachate samples from site L2 (Table 3). In total PAH sums, the dominant pollutant at all the sites investigated was phenanthrene. Correlation between ecotoxicological test results 
Table 3. PAH concentrations in autumn sediment leachates

\begin{tabular}{|l|c|c|c|c|}
\hline \multirow{2}{*}{\multicolumn{2}{|c|}{ Troubsky Brook }} & \multicolumn{3}{|c|}{ Site profile } \\
\cline { 3 - 5 } & $\mathrm{ng} \cdot \mathrm{l}^{-1}$ & $\mathrm{~T} 1$ & $\mathrm{~T} 2$ & 212.2 \\
\hline PAH 6* & $\mathrm{ng} \cdot \mathrm{l}^{-1}$ & $<8.6$ & 19.0 & 729 \\
\hline PAH 15** & $\mathrm{ng} \cdot \mathrm{l}^{-1}$ & 453 & 362 & 423 \\
\hline Phenanthrene*** & 453 & 343 & \\
\hline
\end{tabular}

\begin{tabular}{|c|c|c|c|c|}
\hline \multirow{2}{*}{\multicolumn{2}{|c|}{ Leskava }} & \multicolumn{3}{|c|}{ Site profile } \\
\hline & & L1 & L2 & L3 \\
\hline PAH 6* & $\mathrm{ng} \cdot \mathrm{l}^{-1}$ & 50.3 & 117.3 & 48.0 \\
\hline PAH $15 * *$ & $\mathrm{ng} \cdot \mathrm{l}^{-1}$ & 1752 & 442 & 381 \\
\hline Phenanthrene*** & $\mathrm{ng} \cdot \mathrm{l}^{-1}$ & 1680 & 301 & 328 \\
\hline
\end{tabular}

* PAH 6 - sum of concentrations fluoranthene, benzo (b) fluoranthene, benzo (k) fluoranthene benzo (a) pyrene, benzo $(\mathrm{g}, \mathrm{h}, \mathrm{i})$ perylene, indeno $(1,2,3)$ pyrene (carcinogenic PAH according to WHO)

** PAH 15 - sum of concentrations naphtalene, acenaphtene, fluorene, phenanthrene, anthracene, fluoranthene, pyrene, benzo (a) anthracene, chrysene, benzo (b) fluoranthene, benzo (k) fluoranthene, benzo (a) pyrene, dibenzo $(\mathrm{a}, \mathrm{h})$ anthracene, benzo $(\mathrm{g}, \mathrm{h}, \mathrm{i})$ perylene, indeno $(1,2,3)$ pyrene (hazardous PAH s according to EPA)

*** phenanthrene - dominant PAH

and measured concentrations of contaminants was shown in results of the test with Pseudokirchneriella subcapitata and arsenic $(\mathrm{r}=0.5)$, Vibrio fischeri and mercury $(\mathrm{r}=-0.5)$, Lemna minor and lead $(\mathrm{r}=0.65)$, Sinapis alba and mercury $(\mathrm{r}=0.59)$ and Xenopus laevis and PAH $6(\mathrm{r}=0.66)$ and phenantrene $(\mathrm{r}=0.71)$, but these correlations were not significant. The role of ecotoxicity testing in assessing water quality is evaluated by Chapman (1995). Compared to tests on animals, the tests on autotrophic organisms are used to a lesser extent, although they are often more sensitive and, therefore, they are recommended by Calow (1993) for determination of a number of substances - e.g. surfactants, pesticides, metals, organic substances, industrial wastes, extracts of solid wastes. Stimulatory effects have often been shown in ecotoxicity evaluations of river sediments using tests with autotrophic organisms such as the duckweed and algae (Kolarova-Kukletova et al. 2003). The stimulatory effects have been attributed to a higher content of biogenic elements, i.e. nitrogen and phosphorus, influencing the intensity of eutrophication. Stimulation of Pseudokirchneriella subcapitata has been found only in a few spring samples from the Troubsky Brook, in particular, in the present study sampling sites T1 and T2. Our results of FETAX test suggest that Xenopus embryos are the most sensitive to arsenic and total PAH content in sediment leachates. High concentrations of arsenic and total PAH (sample L1) cause $100 \%$ incidence of malformation of embryos in the extract from autumn sampling. Some authors (Gornati et al. 2002) demonstrated that the arsenic action on embryonic development of Xenopus was via a strong induction of heat-shock protein HSP70 mRNA. The study on the effect of coal tar-based pavement sealer containing a large percentage of PAHs showed the ability of PAHs to affect the growth and development of amphibians (Bryer et al. 2006). The highest mortality of Xenopus embryos was caused by the extract from the sediment L2 from spring sampling. However, neither PAHs nor metal concentrations were increased in this extract. These results indicate the need for further chemical analyses.

The same sensitivity was recorded in the tests using the green alga Pseudokirchneriella subcapitata, duckweed Lemna minor and water flea Daphnia magna. Water fleas belong to organisms highly susceptible to most pollutants (Enserink et al. 1993) such as pesticides containing organophosphates and carbamates (Barata et al. 2007; Svobodova and Faina 1994; Brown et al. 2007). Comparative ecotoxicity results of suspended sediment in the lower Rhone river using Algal fractionation, Microtox ${ }^{\circledR}$ and Daphnia magna bioassays 
by Santiago et al. (1993) were in agreement with our results, when Daphnia magna was found to be the least susceptible. High immobilization of daphnia specimens observed in sample L2 from the spring collection was probably due to the presence of suspended substances in the filtered leachate of the sediment forming flocculation during the test, which disabled their movement when sticking onto their antennae.

\section{Ekotoxikologické hodnocení výluhů ze sedimentů malých vodních toků $\mathbf{v}$ př́íměstské krajině}

Práce hodnotí ekotoxicitu sedimentů dvou malých vodních toků Leskavy a Troubského potoka v brněnské príměstské krajině. Při př́pravě výluhů ze sedimentů byly použity standardní postupy. Ekotoxikologické testy s výluhy sedimentů byly provedeny na sladkovodní řase Pseudokirchneriella subcapitata, vodní cévnaté rostlině Lemna minor, na zástupci bezobratlých - perloočce Daphnia magna, na embryích žab Xenopus laevis a luminiscenčních bakteriích Vibrio fischeri. Možný toxický efekt byl hodnocen i pomocí testu inhibice růstu kořene hořčice bílé Sinapis alba. Kromě testů na Lemna minor, Vibrio fischeri a Xenopus laevis byly všechny testy prováděny v souladu s postupy používanými při hodnocení ekotoxicity odpadů. Naše výsledky ukázaly, že kvalita sedimentů se v průběhu roku průkazně mění, což může být spojeno s nedostatkem srážek v letním období. Signifikantní rozdíly byly zjištěny mezi toxicitou výluhů z různých odběrových profilů, což může ukazovat na vliv bodových zdrojů znečištění. $Z$ použitých ekotoxikologických testů nejcitlivěji reagovaly zelená řasa Pseudokirchneriella subcapitata, bakterie Vibrio fischeri a drápatka vodní Xenopus laevis. Chemickou analýzou výluhu sedimentů byla zjištěna vysoká koncentrace arzenu na odběrovém místě L1 (tok Leskava) a to z jarního i podzimního odběru. Nejvyšší koncentrace organických polutantů byla nalezena ve výluhu sedimentu z podzimního odběru v odběrovém místě L1. Na všech sledovaných profilech byl dominatním polutantem phenanthren jako zástupce PAHs.

\section{Acknowledgements}

This research was supported by the Ministry of Education, Youth and Sports of the Czech Republic Grant No. 6215712402 and Grant Agency Czech Republic Grant No. 103/07/0580.

\section{References}

ASTM E-1439-98, 1999: Standard Guide for Conducting the frog Embryo Teratogenesis Assay - Xenopus (FETAX), 16 p.

Barata C, Damasio J, Lopez MA, Kuster M, de Alda M1, Barcelo D, Riva MC, Raldua D 2007: Combined use of biomarkers and in situ bioasssays in Daphnia magna to monitor environmental hazards of pesticides in the field. Environ Toxicol Chem 26: 370-379

Billen G, Garnier J, Ficht A, Cun C 2001: Modeling the response of the water quality in the Seine river estuary to human activity in its watershed over the last 50 years. Estuaries 24: 977-993

Brown CD, Holmes C, Williams R, Beuke S, van Beinum W, Pemberton E, Wells C 2007: How does crop type influence risk from pesticides to aquatic environment? Environ Toxicol Chem 26:1818-1826

Bryer PJ, Elliott JN, Willingham EJ 2006: The effects of coal tar based pavement sealer on amphibian development and metamorphosis. Ecotoxicology 15: 241-247

Burkholder J, Libra B, Weyer P, Heathcote S, Kolpin D, Thorne PS, Wichman M 2007: Impacts of waste from concentrated animal feeding operations on water quality. Environ Health Persp 115: 308-312

Calow P (ed.) 1993: Handbook of Ecotoxicology. Vol. 1 Blackwell Science Ltd. 478 p.

Chapman JC 1995: The role of ecotoxicity testing in assessing water-quality. Aust J Ecol 20: 20-22

CSN EN 14735, 2007: Characterization of waste - Preparation of waste samples for ecotoxicity tests, $44 \mathrm{p}$.

CSN EN ISO 11348-2, 2000: Water quality - Determination of the inhibitory effect of water samples on the light emission of Vibrio fischeri (Luminiscent bacteria test) - Part 2: Method using liquid-dried bacteria, $19 \mathrm{p}$.

CSN EN ISO 20079, 2007: Water quality - Determination of the toxic effect of water constituents and waste water on duckweed (Lemna minor) - Duckweed growth inhibition test, $25 \mathrm{p}$.

Comoutto L, Chiron S 2005: Comparing pharmaceutical and pesticide loads into a small Mediterranean river. Sci Total Environ 349: 201-210

Enserink 1, De La Haye M, Maas H 1993: Reproductive strategy of Daphnia magna-implications for toxicity tests. Aquat Toxicol 25: 111-123 
Gornati R, Monetti C, Vigetti D, Bosisio S, Fortaner S, Sabbioni E, Bernardini G, Prati M 2002: Arsenic toxicity and HSP70 expression in Xenopus laevis embryos. Atla-Altern Lab Anim 30: 597-603

Hollert H, Heise S, Pudenz S, Brüggemann R, Ahlf W, Braunbeck T 2002: Application of a sediment quality triad and different statistical approaches (Hasse diagrams and fuzzy logic) for the comparative evaluation of small streams. Ecotoxicology 11: 311-321

ISO 5667-12, 1998: Water Quality - Sampling - Part 12: Guidance on sampling bottom sediments, $34 \mathrm{p}$.

Kammann U, Biselli S, Reineke N, Wosniok W, Danischewski D, Hübnerfuss H, Kinder A, Sierts-Herrmann A, Theobald N, Vahl HH, Vobach M, Westendorf J, Steinhart H 2005: Bioassay-directed fractionation of organic extract of marine surface sediments from the North and Baltic Sea; Part II: Results of the biotest battery and development of a biotest index. J Soil Sediment 5: 225-233

Keiter S, Rastall A, Kosmehl T, Wurm K, Erdinger L, Braunbeck T, Hollert H 2006: Ecological Assessment of Sediment, Suspended Matter and Water Samples in the Upper Danube River. Environ Sci Pollut Res 13: 308-319

Kolarova-Kukletova I, Beklova M, Vavrova M 2003: Determination of ecotoxicity in river sediments. Fresen Environ Bull 12: 848-851

Konstantinou IK, Hela DG, Albanis TA 2006: The status of pesticide pollution in surface waters (rivers and lakes) of Greece. Part I. Review on occurrence and levels. Environ Pollut 141: 555-570

Lai VWM, Cullen WR, Ray S 2001: Arsenic speciation in sea scallop gonads. Appl Organometal Chem 15: 490498

Machova J, Svobodova Z, Vykusova B 1994: Ecotoxicological evaluation of extracts from solid industrial wastes. Series: Methodologies, VURH JU Vodnany, No.45, 50 p.

Mast MA, Foreman WT, Skaates SV 2007: Current-use pesticides and organochlorine compounds in precipitation and lake sediment two high-elevation national parks in the Western United States. Arch Environ Contam Toxicol 52: 294-305

Method for the determination of ecotoxicity in wastes 2007: Bulletin of the Ministry of the Environment (ME) 4, pp. 5-14

Perceval O, Couillard Y, Pinel-Alloul B, Bonneris E, Campbell PGC 2006: Long-term trends in accumulated metals $(\mathrm{Cd}, \mathrm{Cu}$ and $\mathrm{Zn})$ and metallothionein in bivalves from lakes within a smelter-impacted region. Sci Total Environ 369: 403-418

Pitter P 1999: Hydrochemie. Vydavatelství VŠCHT Praha, 568 p.

Santiago S, Thomas RL, Larbaigt G, Rossel D, Echeverria MA, Tarradellas J, Loizeau JL, McCarty L, Mayfield CI, Corvi C 1993: Comparative ecotoxicity of suspended sediment in the lower Rhone river using Algal fractionation, Microtox ${ }^{\circledR}$ and Daphnia magna bioassays. Hydrobiologia 252: 231-244

Sun P, Ilora, Basu, Blanchard P, Brice KA, Hites RA 2007: Temporal and spatial trends of atmospheric polychlorinated biphenyl concentrations near the Great Lakes. Environ Sci Technol 41: 1131-1136

Svobodova Z, Faina R 1994: Aquatic testing of trichlorphon in the laboratory and field. Freshwater Field Tests for Hazard Assessment of Chemicals. Lewis Publishers, Boca Raton pp. 361-368 